\title{
The effect of reduced sodium chloride content on the microbiological and biochemical properties of a soft surface-ripened cheese
}

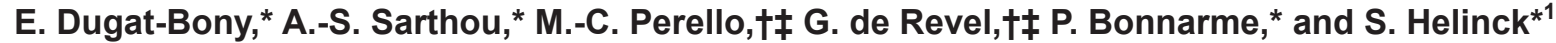 \\ *Unite Mixte de Recherche, Génie et Microbiologie des Procédés Alimentaires, AgroParisTech, INRA, Université Paris-Saclay, 78850, \\ Thiverval-Grignon, France \\ †Institut des Sciences de la Vigne et du Vin, Unité de recherche OEnologie, University of Bordeaux, F-33882 Villenave d'Ornon, France \\ ‡INRA, Institut des Sciences de la Vigne et du Vin, USC 1366 OEnologie, University of Bordeaux, F-33882 Villenave d'Ornon, France
}

\begin{abstract}
Many health authorities have targeted salt reduction in food products as a means to reduce dietary sodium intake due to the harmful effects associated with its excessive consumption. In the present work, we evaluated the effect of reducing sodium chloride $(\mathrm{NaCl})$ content on the microbiological and biochemical characteristics of an experimental surface-ripened cheese. A control cheese $(1.8 \% \mathrm{NaCl})$ and a cheese with a reduced $\mathrm{NaCl}$ content $(1.3 \% \mathrm{NaCl})$ were sampled weekly over a period of $27 \mathrm{~d}$. Reducing $\mathrm{NaCl}$ content induced microbial perturbations such as the lesser development of the yeast Debaryomyces hansenii and the greater development of the gram-negative bacterium Hafnia alvei. This was accompanied by changes in proteolytic kinetics and in profiles of volatile aroma compounds and biogenic amine production. Finally, the development of the spoilage microorganism Pseudomonas fragi was significantly higher in the cheese with a reduced salt content. Key words: salt reduction, cheese microflora, aroma compound, biogenic amine
\end{abstract}

\section{INTRODUCTION}

Excessive sodium intake is known to cause high blood pressure and its associated heart diseases (Mohan and Campbell, 2009). In Europe, mean daily sodium intakes range from approximately 3 to $5 \mathrm{~g}$ (approximately 8 to $11 \mathrm{~g}$ of salt) and are well in excess of dietary needs (approximately $1.5 \mathrm{~g}$ of sodium/day for adults; EFSA, 2006). The World Health Organization has proposed a limit of dietary sodium intake by restricting daily salt intake to less than $5 \mathrm{~g} / \mathrm{d}$ (WHO, 2003). In European and North American countries, processed foods, including cheese products, are estimated to contribute over

Received October 9, 2015.

Accepted December 15, 2015.

${ }^{1}$ Corresponding author: sandra.helinck@agroparistech.fr
$70 \%$ to dietary sodium intake. Thus, sodium reduction in the human diet is currently one of the main objectives for public health agencies (Elliott and Brown, 2007) and, consequently has become a major challenge facing the food industries. In France, dietary guidelines recommend a $20 \%$ reduction of salt in foods to obtain a target of 6.5 to $8 \mathrm{~g}$ of salt intake per day (ANSES, 2012). Cheese is perceived as being a food source that is high in sodium, with amounts that vary depending on the type of cheese. In fact, cheeses such as soft, semihard, and hard cheeses contain between 0.5 and $2.5 \%$ sodium chloride $(\mathrm{NaCl})$, and blue-type cheeses contain between 3 and $5 \% \mathrm{NaCl}$.

Sodium chloride fulfills many important functions in cheese: it modifies the physical properties of the cheese curd and rind, controls the growth of the cheese-ripening microflora, limits the development of undesirable species (comprising both pathogens and spoilage microbes), and contributes to taste and overall consumer satisfaction (Guinee and Fox, 2004; Cruz et al., 2011). Several studies have been conducted to characterize the effect of reducing $\mathrm{NaCl}$ content or partially substituting $\mathrm{NaCl}$ with $\mathrm{KCl}$ on various quality aspects of hard cheeses (Shrestha et al., 2011a,b; Grummer et al., 2012; Hystead et al., 2013; Rulikowska et al., 2013; Porcellato et al., 2014), white brined cheeses (Melilli et al., 2004; Ayyash et al., 2011; Ayyash and Shah, 2011a,b,c; Kamleh et al., 2012; Osaili et al., 2014; Thibaudeau et al., 2015), and cream cheeses (Møller et al., 2012). However, there is still a lack of information regarding soft cheeses and, specifically, surface-ripened cheeses.

Soft cheeses represent $40 \%$ of the total ripened cheese produced in France. Such products generally contain $\mathrm{NaCl}$ at levels that vary from 1.5 to $2.3 \%$. The quality of surface-ripened soft cheeses essentially relies on good development of a rind microbial community, originating from several reservoirs (Irlinger et al., 2015). In soft smear-ripened cheeses, the surface microflora is composed of various species of yeasts, as well as gram-positive and gram-negative bacteria. Salt level has an effect on the growth of bacteria isolated 
from surface-ripened cheeses, including Brevibacterium, Corynebacterium, Microbacterium, and Staphylococcus (Mounier et al., 2007). Thus, $\mathrm{NaCl}$ content could be a major technological factor controlling underlying ecosystem assembly and behavior. Modifying $\mathrm{NaCl}$ content in soft smear-ripened cheeses may affect all biochemical processes sustained by surface microorganism activity, including proteolysis and the production of various secondary metabolites (e.g., aroma compounds and biogenic amines). Furthermore, by changing the indigenous microflora, the natural barrier effect against undesirable species may be altered as well.

The objective of this study was to investigate the effect of reduced $\mathrm{NaCl}$ content on microbiological balance with respect to both the cheese-ripening microflora and a spoilage microorganism (Pseudomonas fragi), proteolysis, aromatic qualities, and the biogenic amine production profile of an experimental surface-ripened cheese similar to Munster-Livarot-type cheese.

\section{MATERIALS AND METHODS}

\section{Strains and Growth Conditions}

The 9 microorganisms that composed the model microbial community were Corynebacterium casei UCMA 3821 (obtained from the Laboratoire des Microorganismes d'Intérêt Laitier et Alimentaire, Caen, France), Brevibacterium aurantiacum ATCC 9174, Geotrichum candidum ATCC 204307 (both from the American Type Culture Collection, Rockville, MD), Arthrobacter arilaitensis CIP 108037 (from the collection of the Institut Pasteur, Paris, France), and Staphylococcus equorum Mu2, Hafnia alvei GB001, Lactococcus lactis ssp. lactis S3+ and its protease-negative variant S3-, Kluyveromyces lactis 3550, and Debaryomyces hansenii 304 (from the culture collection of the Génie et Microbiologie des Procédés Alimentaires, INRA, Thiverval-Grignon, France). The spoilage microorganism, Pseudomonas fragi 1E26, was kindly provided by C. Delbes-Paus (from the culture collection of the Unité de Recherches Fromagères, INRA, Aurillac, France). All strains were originally isolated from cheese. The lactic acid bacteria Lactococcus lactis ssp. lactis S3+ and S3- were grown for $24 \mathrm{~h}$ at $30^{\circ} \mathrm{C}$ under static conditions in M17 lactose (0.5\%) broth (Biokar Diagnostics, Beauvais, France), inoculated at $3 \%$ in reconstituted skim milk $(100 \mathrm{~g} / \mathrm{L}$, Difco Laboratories, Detroit, MI), and then incubated for $16 \mathrm{~h}$ at $30^{\circ} \mathrm{C}$. All other bacteria were grown under aerobic conditions (using a rotary shaker at $150 \mathrm{rpm}$ ) at $25^{\circ} \mathrm{C}$ for $48 \mathrm{~h}$ in $50-\mathrm{mL}$ conical flasks containing 10 $\mathrm{mL}$ of brain heart infusion broth (Biokar Diagnostics). The yeasts were grown under the same conditions, ex- cept that potato dextrose broth (Biokar Diagnostics) was used as the growth medium.

\section{Cheese Production}

Sterile model surface-ripened cheeses were produced in a manner similar to that described in previous studies (Mounier et al., 2008; Dugat-Bony et al., 2015). Such a model cheese has been shown to be representative of Munster-Livarot-type cheese in terms of its sensory properties (Bonaïti et al., 2005). Briefly, pilotscale cheese production (coagulation, cutting, draining, and molding of the curd) was carried out under aseptic conditions in a sterilized $3-\mathrm{m}^{3}$ chamber, as previously described (Mounier et al., 2008). Only Lactococcus lactis ssp. lactis $\mathrm{S} 3+/ \mathrm{S} 3$ - were inoculated at this stage. One kilogram of the resulting cheese curd was crumbled under sterile conditions and mixed 3 times with 234 $\mathrm{mL}$ of 90 or $64 \mathrm{~g} / \mathrm{L} \mathrm{NaCl}$ for $10 \mathrm{~s}$ at maximum speed using a Waring blender to obtain a homogeneous cheese paste with a salt content of approximately 18 (control level) and 13 (reduced level) g/kg, respectively. Freshly prepared microbial solutions $\left(2 \times 10^{9} \mathrm{cfu} / \mathrm{mL}\right.$ in physiological saline solution for bacteria, and $2 \times 10^{7} \mathrm{cfu} /$ $\mathrm{mL}$ for D. hansenii and K. lactis, and $2 \times 10^{4} \mathrm{cfu} / \mathrm{mL}$ for $G$. candidum) were then added to the cheese. The 5 ripening bacteria were inoculated at a concentration of $10^{6} \mathrm{cfu} / \mathrm{g}$ of cheese; D. hansenii and K. lactis were inoculated at $10^{4} \mathrm{cfu} / \mathrm{g}$ of cheese; and G. candidum was inoculated at $10^{2} \mathrm{cfu} / \mathrm{g}$ of cheese. In some experiments, P. fragi was inoculated at $10^{4} \mathrm{cfu} / \mathrm{g}$ of cheese. Twentyfive grams of the inoculated cheese paste was then transferred to sterile crystallizing basins with a diameter of $5.6 \mathrm{~cm}$. The model cheeses were ripened for $1 \mathrm{~d}$ at $17^{\circ} \mathrm{C}$ and $93 \%$ relative humidity and then for $26 \mathrm{~d}$ at $12^{\circ} \mathrm{C}$ and $97 \%$ relative humidity. At least 3 cheeses for each salting condition were taken at regular time intervals during the ripening process $(0,6,13,20$, and $27 \mathrm{~d})$. The entire cheese was homogenized at $4^{\circ} \mathrm{C}$ under sterile conditions, and $1 \mathrm{~g}$ was sampled and transferred to a sterile container for microbiological analysis. Cheeses were then stored at $-80^{\circ} \mathrm{C}$ until quantitative PCR assay, biogenic amine, and aroma compound analysis.

\section{Physicochemical Analysis}

Samples were analyzed for $\mathrm{pH}$, water activity $\left(\mathbf{a}_{\mathrm{w}}\right)$, and $\mathrm{NaCl}$ content. Cheese $\mathrm{pH}$ was measured after homogenization of the entire cheese (both surface and core) with a Blueline 27 surface electrode (Schott, VWR, Fontenay-sous-Bois, France). Water activity was measured on $5 \mathrm{~g}$ of cheese using an electronic water activity meter (Novasina, Labmaster, Lachen, Switzer- 
land). For $\mathrm{NaCl}$ content, the sodium ion concentration was determined on a cheese suspension prepared from 1 $\mathrm{g}$ of cheese and $9 \mathrm{~mL}$ of distilled water using an Orion Dual Star pH/ISE meter (Thermo Scientific, Villebonsur-Yvette, France). The $\mathrm{NaCl}$ content was measured at d 6 when diffusion of salt was stable within the cheese.

\section{Microbiological Analysis}

One gram of the cheese was diluted to 1:10 in sterile saline solution $(9 \mathrm{~g} / \mathrm{L} \mathrm{NaCl})$ and homogenized with an Ultra Turrax Homogenizer (Labortechnik, Staufen, Germany) at 8,000 rpm for $1 \mathrm{~min}$. Microorganisms were enumerated by surface plating in duplicate on specific agar base medium. Total ripening bacteria were enumerated on brain heart infusion agar supplemented with $22.5 \mathrm{mg} / \mathrm{L}$ amphotericin $\mathrm{B}$ after 3 to 5 $\mathrm{d}$ of incubation at $25^{\circ} \mathrm{C}$ under aerobic conditions, and then transferred for exposure to natural light for colony pigmentation. All bacterial strains were differentiated by their different morphotypes. The yeast population was determined on yeast-glucose-chloramphenicol agar supplemented with $0.01 \mathrm{~g} / \mathrm{L}$ tetrazolium chloride after 2 to $3 \mathrm{~d}$ of incubation at $25^{\circ} \mathrm{C}$ under aerobic conditions. All yeast strains were differentiated by their different morphotypes. A population of P. fragi 1E26 was selectively determined on CFC medium (Biokar Diagnostics) supplemented with $5 \mathrm{mg} / \mathrm{L}$ vancomycin.

\section{Quantitative PCR Assay}

DNA Extraction from Cheese. A cheese sample $(0.5 \mathrm{~g})$ was homogenized with $500 \mu \mathrm{L}$ of $1 \times$ Tris-EDTA buffer (Tris $10 \mathrm{~m} M$, EDTA $1 \mathrm{~m} M$ ) for $20 \mathrm{~s}$ at 6,500 rpm using a Precellys homogenizer (Bertin Technologies, Montigny-le-Bretonneux, France) without beads. Five hundred microliters of the cheese suspension was transferred to a $2-\mathrm{mL}$ tube containing $0.2 \mathrm{~g}$ of zirconium beads (diameter: 0.1 and $0.5 \mathrm{~mm}, 50 / 50$; BioSpec Products, Bartlesville, OK) and $75 \mu \mathrm{L}$ of an enzymatic solution containing lysozyme $(54.5 \mathrm{mg} / \mathrm{mL}$, Sigma, St. Louis, MO) and lyticase (1,300 U/mL, Sigma). After incubation at $37^{\circ} \mathrm{C}$ for $30 \mathrm{~min}, 40 \mu \mathrm{L}$ of proteinase $\mathrm{K}(14 \mathrm{mg} / \mathrm{mL}$, Sigma) and $100 \mu \mathrm{L}$ of SDS $(200 \mathrm{~g} / \mathrm{L}$, Sigma) were added. The tube was incubated at $55^{\circ} \mathrm{C}$ for $30 \mathrm{~min}$. The following steps of the DNA extraction procedure, including phenol/chloroform extraction, RNaseA treatment, and ethanol precipitation, were performed as previously described (Monnet et al., 2006). The DNA pellet was resuspended in $100 \mu \mathrm{L}$ of $1 \times$ Tris-EDTA buffer and quantified using a NanoDrop ND-1000 spectrophotometer (NanoDrop Technologies, Wilmington, DE).
Quantitative PCR. Two primer pairs targeting the 16Sr RNA gene, and already described (Bergmark et al., 2012), were used in this study: Pse435F (ACTTTAAGTTGGGAGGAAGGG) and Pse686R (ACACAGGAAATTCCACCACCC), which is specific to the Pseudomonas genus, and the universal bacterial primer pair Eub 338F (ACTCCTACGGGAGGCAGCAG) and Eub 518 R (ATTACCGCGGCTGCTGG). The PCR amplifications and analyses were done using a Bio-Rad CFX Connect real-time PCR detection system (BioRad, Marnes-la-Coquette, France) and a SYBR Green real-time PCR kit (SsoAdvanced Universal SYBR Green Supermix, Bio-Rad, Hercules, CA). The thermocycling program consisted of initial denaturation at $95^{\circ} \mathrm{C}$ for 5 min, followed by 40 cycles of denaturation $\left(95^{\circ} \mathrm{C} / 5 \mathrm{~s}\right)$ and annealing/extension $\left(60^{\circ} \mathrm{C} / 20 \mathrm{~s}\right.$ for the universal primer pair and $65^{\circ} \mathrm{C} / 20 \mathrm{~s}$ for the Pseudomonas-specific primer pair). Fluorescence acquisition was done at the end of each extension. After real-time PCR, a melting curve analysis was performed by measuring fluorescence during heating from 65 to $95^{\circ} \mathrm{C}$ with $0.2^{\circ} \mathrm{C}$ increments. Quantification cycle $(\mathbf{C q})$ values were determined with CFX manager software (version 3.1; Bio-Rad), using the regression determination mode. For each sample, the $\mathrm{Cq}$ value obtained with the universal primer pair was used to normalize the value obtained with that specific to Pseudomonas using the $\log _{2}(\Delta \Delta \mathrm{Cq})$ method. The control sample used for the comparison corresponded to a cheese without $P$. fragi.

\section{Biochemical Analysis}

Proteolysis Index. A cheese suspension was prepared from $2 \mathrm{~g}$ of cheese and $18 \mathrm{~mL}$ of distilled water. It was homogenized for $2 \mathrm{~min}$ at 25,000 rpm using a mechanical blender (Ultra-Turrax model T25, Labortechnik). This suspension was used for total nitrogen $(\mathbf{T N})$, noncasein nitrogen (referred to as acidsoluble nitrogen, ASN), and NPN content measures, as previously described (Leclercq-Perlat et al., 2000b). The TN content was directly measured on $2 \mathrm{~mL}$ of the cheese suspension using the Kjeldahl method according to standard NF EN ISO 8968-1 (ISO, 2014). The ASN content was measured according to the procedure described in standard NF ISO 27871 (ISO, 2011). Five milliliters of the cheese suspension was adjusted to $\mathrm{pH}$ 4.6 using $5 \mathrm{~N} \mathrm{HCl}$ and centrifuged for $30 \mathrm{~min}$ at 2,600 $\times g$. The supernatant was filtered through a nylon syringe filter with a porosity of $0.22 \mu \mathrm{m}$ (AIT, Houilles, France). The nitrogen content of this soluble fraction was measured using the Kjeldahl method according to standard NF EN ISO 8968-1 (ISO, 2014). For NPN, $7 \mathrm{~mL}$ of the cheese suspension was mixed with $10 \mathrm{~mL}$ 
of distilled water and $7 \mathrm{~mL}$ of trichloroacetic acid (240 $\mathrm{g} / \mathrm{L}$ ) and then homogenized using a mechanical blender (2 min, 25,000 rpm). The mixture was incubated for $20 \mathrm{~min}$ at room temperature and filtered through a nylon syringe filter with a porosity of $0.22 \mu \mathrm{m}$ (AIT). The ratios ASN:TN and NPN:TN were used as cheeseripening indicators.

Volatile Aroma Compound Profile. Volatile aroma compounds were quantified at the end of ripening (d 27) in 5 independent cheeses for each condition. Before analysis, the cheese samples were thawed at $4^{\circ} \mathrm{C}$, vigorously shaken, and diluted $(1 / 6)$ with a cold solution of 2,5-dimethylpyrazine $(324 \mu \mathrm{g} / \mathrm{L})$. This solution was used as the internal standard for the experiment. Five milliliters of the mixture was analyzed using a dynamic headspace analyzer (purge-and-trap concentrator, Tekmar-Dohrmann 3100, Tekmar Inc., Cincinnati, $\mathrm{OH}$ ) coupled to a gas chromatograph (model 6890, Agilent Technologies, Palo Alto, CA) and a mass spectrometer detector (MSD 5973 inert quadrupole mass spectrometer, Agilent Technologies), as previously described (Irlinger et al., 2012). The concentrations of the volatile compounds produced were quantified from a standard curve made with 5 pure compounds purchased from Sigma-Aldrich (St. Louis, MO), incorporated into curd. Before the addition of compounds, the curd was diluted $(1 / 6)$ with a solution of 2,5-dimethylpyrazine $(324 \mu \mathrm{g} / \mathrm{L})$. The concentrations of volatile sulfur compounds, aldehydes, alcohols, esters, and ketones were quantified from a standard curve made with dimethyl disulfide (DMDS), 3-methyl butanal, 3-methyl butanol, acetic acid 3-methylbutyl acetate, and 2-heptanone, respectively. The results were expressed in micrograms of compound per kilogram of cheese.

Biogenic Amine Concentration. Biogenic amines (BA) were quantified in 4 different culture conditions at the end of ripening (d 27): in model cheeses with 1.8 and $1.3 \%$ of salt content, and in the presence and absence of $P$. fragi. The BA were quantified in 4 independent cheeses for each condition. Cheese samples (5 g) were homogenized in $10 \mathrm{~mL}$ of $0.1 \mathrm{~N} \mathrm{HCl}$ and centrifuged at $12,000 \times g\left(20 \mathrm{~min}, 4^{\circ} \mathrm{C}\right)$. The supernatant was recovered and extraction was performed again with $10 \mathrm{~mL}$ of $0.1 \mathrm{~N} \mathrm{HCl}$. The 2 acid extracts were then mixed and made up to $20 \mathrm{~mL}$ with $0.1 \mathrm{~N} \mathrm{HCl}$. This extract was filtered $(0.45 \mu \mathrm{m})$ and stored at $-20^{\circ} \mathrm{C}$ until analysis of BA. A standard solution containing a mixture of histamine, tyramine, tryptamine, phenylethylamine, putrescine, isoamylamine, and cadaverine $(500 \mathrm{mg} / \mathrm{L}$ each) in a hydroalcoholic solution $(50 \% \mathrm{vol} /$ vol) was used, in different dilutions, to quantify the BA present in the samples. Separation, identification, and quantification of these compounds were performed with
HPLC following the procedure previously described by Helinck et al. (2013).

\section{Statistical Analysis}

Differences in the results obtained between the control cheeses and those with reduced $\mathrm{NaCl}$ content were assessed using a dependent Student test for pairedsamples. Means with a $P$-value $<0.05$ were considered significantly different between the 2 groups.

\section{RESULTS}

\section{Physicochemical Parameters of Cheeses}

The $\mathrm{NaCl}$ content was $17.9 \pm 0.1 \mathrm{~g} / \mathrm{kg}$ in the control cheese and $12.9 \pm 0.2 \mathrm{~g} / \mathrm{kg}$ in the reduced-salt cheese. The $\mathrm{pH}$ values ranged from $4.69 \pm 0.01$ at $\mathrm{d} 0$ to 8.35 \pm 0.06 in the control cheese and to $7.71 \pm 0.16$ in the cheese with a reduced $\mathrm{NaCl}$ content at d 27 (Figure 1). No major difference was observed between $a_{w}$ in the control cheese $(1.8 \% \mathrm{NaCl})$ and in the reduced-salt cheese $(1.3 \% \mathrm{NaCl})$ during ripening. At $\mathrm{d} 27$, the $\mathrm{a}_{\mathrm{w}}$ value was $0.962 \pm 0.001$ for the control cheese and 0.967 \pm 0.001 for the cheese with reduced $\mathrm{NaCl}$ content.

\section{Effect of Reducing Salt Content on the Technological Microflora}

The evolution of yeast and bacterial counts over time was similar during the entire ripening period in the control and reduced- $\mathrm{NaCl}$ cheeses (Figure 1). In both cheeses, growth measurements revealed the early development of yeasts during the first 2 wk of ripening, especially $D$. hansenii and $G$. candidum, followed by the development of acid-sensitive bacteria (A. arilaitensis, H. alvei, B. aurantiacum, S. equorum, and C. casei) between $\mathrm{d} 6$ and 27 .

However, reducing the $\mathrm{NaCl}$ content had a strong effect on the development of each individual cheeseripening microorganism (Figure 1). Reducing the $\mathrm{NaCl}$ content resulted in lesser development of $D$. hansenii $(7.63 \pm 0.12$ vs. $8.14 \pm 0.18 \mathrm{log} \mathrm{cfu} / \mathrm{g}$ at $\mathrm{d} 6$, Student's test, $P<0.05 ; 7.47 \pm 0.09$ vs. $8.03 \pm 0.11 \log \mathrm{cfu} / \mathrm{g}$ at d 13, Student's test, $P<0.05)$ and slightly greater development of $G$. candidum $(7.31 \pm 0.01$ vs. $7.12 \pm$ $0.08 \mathrm{log} \mathrm{cfu} / \mathrm{g}$ at $\mathrm{d} 6$, not statistically significant; 7.91 \pm 0.08 vs. $7.68 \pm 0.03 \log \mathrm{cfu} / \mathrm{g}$ at $\mathrm{d} 13$, not statistically significant). This was accompanied by a slower increase in the $\mathrm{pH}$ values at $\mathrm{d} 20(7.05 \pm 0.04$ vs. 7.71 \pm 0.08 , Student's test, $P<0.05)$. Furthermore, the lesser development of most ripening bacteria except $H$. alvei was reported in the reduced- $\mathrm{NaCl}$ cheese. The 
A

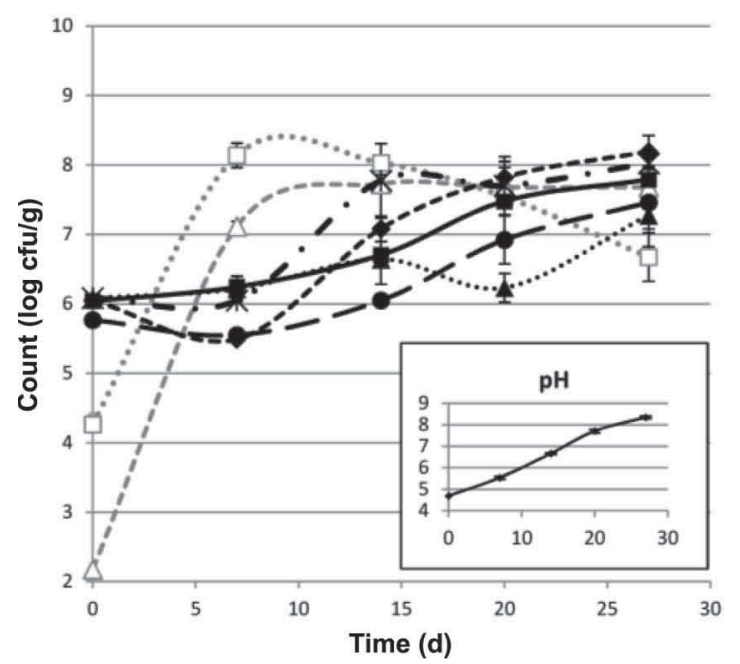

B

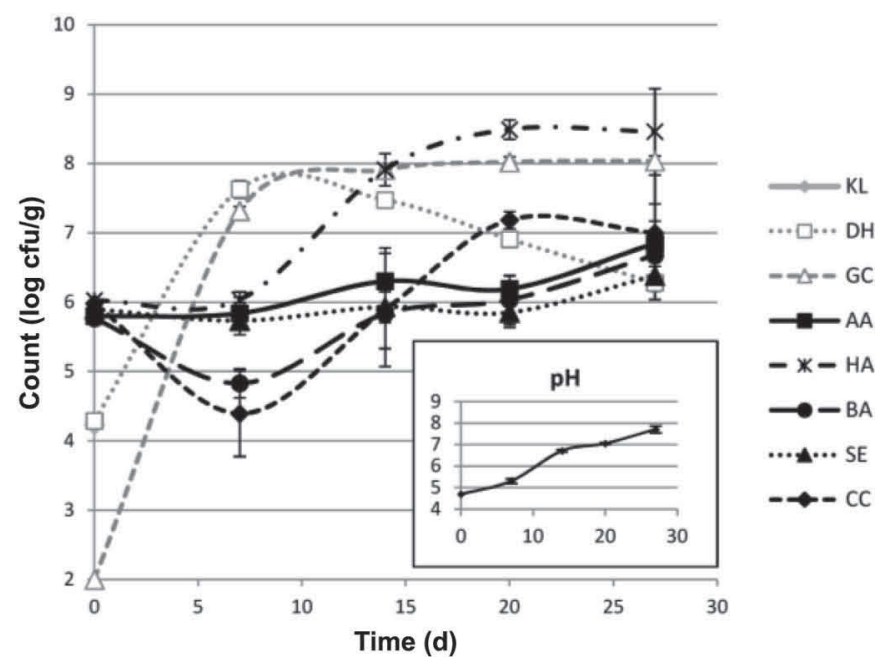

Figure 1. Changes in the microbial community structure during surface-ripened cheese maturation. Microbiological counts and $\mathrm{pH}$ values were measured for $(\mathrm{A})$ control cheeses $(1.8 \% \mathrm{NaCl})$ and $(\mathrm{B})$ cheeses with a reduced $\mathrm{NaCl}$ content $(1.3 \% \mathrm{NaCl})$. $\mathrm{KL}=$ Kluyveromyces lactis, $\mathrm{DH}$ $=$ Debaryomyces hansenii, $\mathrm{GC}=$ Geotrichum candidum, $\mathrm{AA}=$ Arthrobacter arilaitensis, $\mathrm{HA}=$ Hafnia alvei, $\mathrm{BA}=$ Brevibacterium aurantiacum, $\mathrm{SE}=$ Staphylococcus equorum, $\mathrm{CC}=$ Corynebacterium casei. Error bars represent $\mathrm{SD}(\mathrm{n}=3)$.

population of $H$. alvei was, in fact, significantly higher in the reduced- $\mathrm{NaCl}$ cheese from $\mathrm{d} 20$ to the end of ripening, with counts of $8.49 \pm 0.14$ and $8.46 \pm 0.62 \mathrm{log}$ $\mathrm{cfu} / \mathrm{g}$ at d 20 and 27, respectively, compared with 7.70 \pm 0.42 and $8.02 \pm 0.09 \mathrm{log} \mathrm{cfu} / \mathrm{g}$ in the control cheese (Student's test, $P<0.05$ ).

\section{Effect of Reducing Salt Content on the Growth of $P$. fragi}

In this experiment, $P$. fragi was added to model cheeses (both control and reduced-salt cheeses) containing the cheese-ripening microflora. The development of cheeseripening yeasts and bacteria was similar in the presence and absence of $P$. fragi in cheeses (data not shown). Microbial counts indicated greater development of $P$. fragi in cheeses with a reduced $\mathrm{NaCl}$ content (Table 1). This species reached $6.19 \pm 0.47 \mathrm{log} \mathrm{cfu} / \mathrm{g}$ at the end of ripening in the cheese with $1.3 \% \mathrm{NaCl}$, which was significantly higher than $4.94 \pm 0.41 \mathrm{log} \mathrm{cfu} / \mathrm{g}$ in the cheese with $1.8 \% \mathrm{NaCl}$ (Student's test, $P<0.05$ ). This result was confirmed by quantitative PCR (Student's test, $P<0.05)$.

\section{Effect of Reducing Salt Content on Proteolysis}

The concentrations of different nitrogen fractions were determined to evaluate the influence of reducing $\mathrm{NaCl}$ content on proteolysis activity. Changes in the ASN:TN and NPN:TN ratios during the ripening period of both controls and reduced-salt cheeses are shown in Figure 2.

The ASN:TN ratio is used as an index of the degree of primary proteolysis in cheese. This index increased from d 1 to 27 in our experimental cheeses. No significant difference was observed until d 27 , when it reached $71 \%$ in the control cheese and $76 \%$ in the reduced- $\mathrm{NaCl}$ cheese (Student's test, $P<0.05)$. The NPN:TN ratio, reflecting secondary proteolysis, increased more rapidly in cheese with a reduced $\mathrm{NaCl}$ content than in the control cheese. Significant differences were observed for this ratio from d 6 to 27, except at d 13 (Student's test, $P<0.05)$. At $\mathrm{d} 27$, the NPN:TN ratio reached $57 \%$ in the control cheese and $61 \%$ in the reduced- $\mathrm{NaCl}$ cheese. Overall, these results indicate that reducing $\mathrm{NaCl}$ con-

Table 1. Development of Pseudomonas fragi in control cheeses (1.8\% $\mathrm{NaCl})$ and reduced- $\mathrm{NaCl}$ cheese $(1.3 \% \mathrm{NaCl})$

\begin{tabular}{lccccc}
\hline & \multicolumn{2}{c}{$\begin{array}{c}\text { Average microbial count } \\
(\log )\end{array}$} & & \multicolumn{2}{c}{$\mathrm{qPCR}^{2}\left[\log _{2}(\Delta \Delta \mathrm{Cq})\right]^{1}$} \\
\cline { 2 - 3 } \cline { 5 - 6 } $\begin{array}{l}\text { Ripening } \\
\text { time }(\mathrm{d})\end{array}$ & $1.8 \% \mathrm{NaCl}$ & $1.3 \% \mathrm{NaCl}$ & & $1.8 \% \mathrm{NaCl}$ & $1.3 \% \mathrm{NaCl}$ \\
\hline 6 & $4.41^{*}$ & $4.53^{*}$ & & $\mathrm{NA}^{2}$ & $\mathrm{NA}$ \\
13 & 4.87 & 5.08 & & $\mathrm{NA}$ & $\mathrm{NA}$ \\
20 & $4.57^{*}$ & $5.56^{*}$ & & 1.12 & 1.95 \\
27 & $4.94^{*}$ & $6.19^{*}$ & & $0.86^{*}$ & $4.97^{*}$ \\
\hline
\end{tabular}

${ }^{1}$ Quantitative PCR as measured by quantification cycle $(\mathrm{Cq})$ method. ${ }^{2} \mathrm{NA}=$ data not available.

*Statistically significant difference between control and reduced-NaCl cheeses at $P<0.05$ (by Student's $t$-test). 


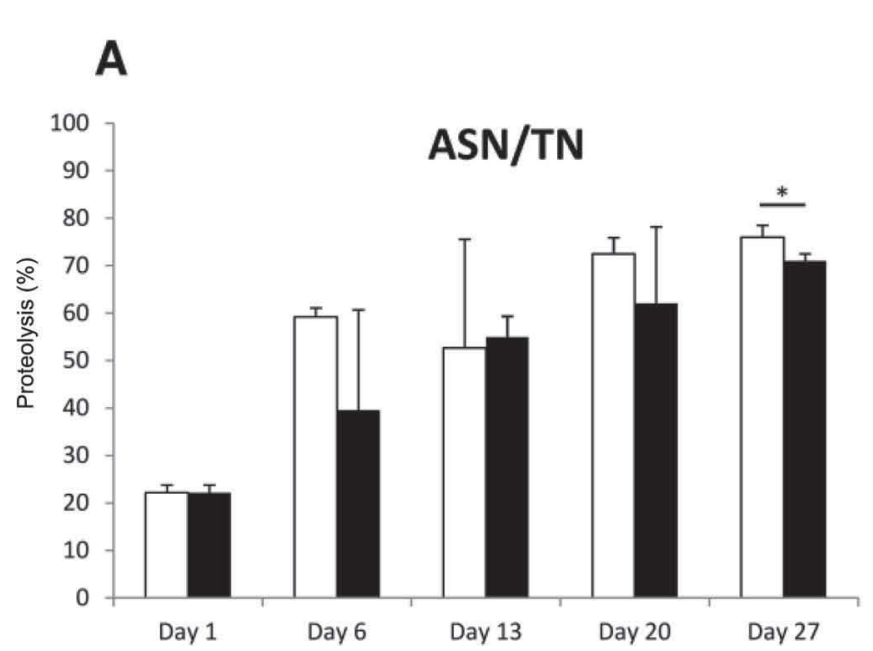

\section{$\square 1.3$ \\ — 1.8}

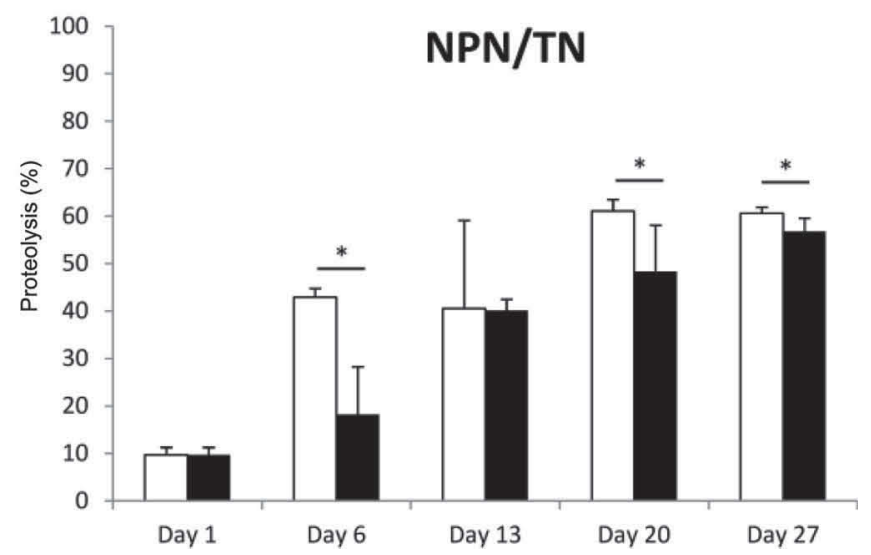

Figure 2. Comparison of the evolution of the proteolysis index during the maturation of control cheeses $(1.8 \% \mathrm{NaCl})$ and cheeses with a reduced salt content $(1.3 \% \mathrm{NaCl})$. (A) Primary proteolysis index, expressed as a percentage, was calculated by dividing the concentration measured in the acid-soluble nitrogen fraction (ASN) by the concentration measured in the total nitrogen fraction (TN) and multiplied by 100; (B) secondary proteolysis index, expressed as a percentage, was calculated by dividing the concentration measured in the NPN fraction by the concentration measured in the TN fraction. Statistically significant differences between the 2 conditions (Student's test, $P<0.05$ ) are highlighted with asterisks. Error bars represent SD $(\mathrm{n}=3)$.

tent in our model cheese would accelerate and increase proteolytic activities, especially secondary proteolysis.

\section{Effect of Reducing Salt Content on Volatile Aroma Compound Profiles}

The total volatile compounds produced by the microflora after $27 \mathrm{~d}$ of ripening in the control cheese and in the cheese with reduced salt content were significantly different (Student's test, $P<0.05$ ). As shown in Table 2 , the highest levels of aroma compounds were detected in cheese with reduced salt content. High levels of sulfur compounds (e.g., DMDS, methanethiol, and methylthioacetate) and alcohols (e.g., ethanol, 2-propanol, 3-methyl-1-butanol, and 2-methyl-1-butanol) were measured in the cheese with reduced salt content. Moreover, we detected variations with respect to a variety of volatile compounds produced, depending on the salt level. For example, 2 esters, hexanoic acid ethyl ester and acetic acid ethyl ester, were only found in the cheese with reduced salt content.

\section{Effect of Reducing Salt Content on Production of Biogenic Amines}

Biogenic amines were quantified at the end of ripening in model cheeses with $1.8 \%$ and $1.3 \%$ salt contents, in the presence and absence of $P$. fragi (Supplemental Table S1; http://dx.doi.org/10.3168/jds.2015-10502). At d 0, BA were detected at trace levels with a total level of $1.7 \mathrm{mg} / \mathrm{kg}$ of cheese. At d 27, among the $7 \mathrm{BA}$ analyzed, histamine and isoamylamine were detected at low levels ( $<3.8$ and $0.1 \mathrm{mg} / \mathrm{kg}$, respectively), whereas tyramine, tryptamine, and phenylethylamine were not detected. Only putrescine and cadaverine were detected at high levels, and differences were observed between control cheeses and reduced- $\mathrm{NaCl}$ cheeses, regardless of the presence or absence of $P$. fragi. Putrescine was detected at significantly higher levels in reduced- $\mathrm{NaCl}$ cheese than in control cheese (in the absence of $P$. fragi): $54.1 \pm 40.1$ versus $11.4 \pm 5.7 \mathrm{mg} / \mathrm{kg}$ of cheese (Student's test, $P<0.05$ ). Similarly, cadaverine was detected at significantly higher levels in reduced-NaCl cheese than in control cheeses: $460.3 \pm 153.8$ versus $335.9 \pm 164.9 \mathrm{mg} / \mathrm{kg}$ of cheese (Student's test, $P<$ $0.05)$.

\section{DISCUSSION}

Reduction of salt levels in food products such as cheese has been undertaken in various countries. Doyle and Glass (2010) described the significant positive economic benefit that widespread reduction in dietary sodium would achieve. Physicochemical, microbiological, and sensory studies are therefore needed to evaluate the potential effect of reducing sodium content in cheese. To date, such studies have been carried out essentially on hard and semi-hard cheeses (Rulikowska et al., 2013; Porcellato et al., 2014; Soares et al., 2015) and Mozzarella cheese (Arboatti et al., 2014). We decided to provide similar data on soft surface-ripened cheese, which represents an important part of cheese 
Table 2. Volatile compound levels $(\mu \mathrm{g} / \mathrm{kg}$ ) detected in cheeses (means and SD of 5 independent cheeses) after 27 d of ripening ${ }^{1}$

\begin{tabular}{|c|c|c|c|c|}
\hline \multirow[b]{2}{*}{ Compound } & \multicolumn{2}{|c|}{ Control cheese } & \multicolumn{2}{|c|}{ Cheese with $1.3 \% \mathrm{NaCl}$} \\
\hline & Mean & $\mathrm{SD}$ & Mean & $\mathrm{SD}$ \\
\hline Methanethiol & $62^{*}$ & 18 & $159^{*}$ & 63 \\
\hline Dimethyl disulfide & $1,262^{*}$ & 406 & $3,235^{*}$ & 1,269 \\
\hline Dimethyl trisulfide & 39 & 21 & 140 & 97 \\
\hline S-Methyl thioacetate & $63^{*}$ & 16 & $351^{*}$ & 180 \\
\hline 2,4-Dithiapentane & $27^{*}$ & 12 & $66^{*}$ & 25 \\
\hline Total & 1,453 & & 3.950 & \\
\hline 2-Methyl propanal & $4^{*}$ & 1 & $22^{*}$ & 8 \\
\hline 3-Methyl butanal & $43^{*}$ & 27 & $95^{*}$ & 30 \\
\hline 2-Methyl butanal & $3^{*}$ & 2 & $25^{*}$ & 6 \\
\hline Total & 50 & & 142 & \\
\hline Ethanol & $7^{*}$ & 7 & $316^{*}$ & 75 \\
\hline 2-Propanol & $291^{*}$ & 164 & $616^{*}$ & 331 \\
\hline 2-Butanol & $4^{*}$ & 3 & $0^{*}$ & 0 \\
\hline 2-Methyl-1-propanol & $10^{*}$ & 6 & $160^{*}$ & 31 \\
\hline 3-Methyl-1-butanol & $109^{*}$ & 61 & $515^{*}$ & 99 \\
\hline 2-Methyl-1-butanol & $14^{*}$ & 6 & $179^{*}$ & 26 \\
\hline Total & 435 & & 1,785 & \\
\hline Thiobis-methane & 43 & 20 & 120 & 114 \\
\hline 3-Methyl pentane & 2 & 3 & 18 & 18 \\
\hline 2-Propanone & 971 & 518 & 586 & 436 \\
\hline 2-Pentanone & $12^{*}$ & 4 & $4^{*}$ & 5 \\
\hline 2-Heptanone & $32 *$ & 7 & $49^{*}$ & 12 \\
\hline Octane & $14^{*}$ & 3 & $54^{*}$ & 13 \\
\hline Total & 1,073 & & 831 & \\
\hline Hexanoic acid ethyl ester & 0 & 0 & 244 & 311 \\
\hline Acetic acid ethyl ester & $0^{*}$ & 0 & $39^{*}$ & 19 \\
\hline Total & 0 & & 282 & \\
\hline
\end{tabular}

*Statistically significant between control and reduced-NaCl cheeses at $P<0.05$ (by Student's $t$-test).

production in France. Compared with other types of cheeses, soft cheeses harbor a rich and diverse nonlactic microflora that successively establishes itself at the surface of the cheese (Irlinger and Mounier, 2009; Irlinger et al., 2015). Thus, modifying environmental conditions by reducing $\mathrm{NaCl}$ content might induce significant changes in the development of such microflora and, consequently, in cheese quality.

Water activity, which depends on the level of moisture and the concentration of low-molecular-weight solutes including $\mathrm{NaCl}$, is a key physical parameter controlling the development of microbial species in cheese (Guinee and Fox, 2004). It is commonly accepted that reduction in $\mathrm{NaCl}$ content results in modification of $\mathrm{a}_{\mathrm{w}}$. Rulikowska et al. (2013) reported a strong influence of $\mathrm{NaCl}$ concentration $\left(0.5\right.$ or $3 \%$ ) on $\mathrm{a}_{\mathrm{w}}$ in Cheddar cheese. However, $a_{w}$ values were very similar for salt contents ranging from 1.2 to $1.8 \%$ in Cheddar cheese (Rulikowska et al., 2013) and Mozzarella (Arboatti et al., 2014). In our experiments, no major difference in $\mathrm{a}_{\mathrm{w}}$ was observed between control cheese and cheese with a reduced $\mathrm{NaCl}$ content during the entire ripening period.

We nevertheless observed differences in the growth kinetics of some of the cheese-ripening microorganisms; for example, D. hansenii was found to develop less in cheese with a reduced $\mathrm{NaCl}$ content (Figure 1). Because this species actively consumes lactate in cheese products (Leclercq-Perlat et al., 2000a), this could explain the slower increase in the $\mathrm{pH}$ of the cheese with reduced $\mathrm{NaCl}$ content $(\mathrm{pH} 7.71 \pm 0.16$ at d 27) compared with the control cheese (pH $8.35 \pm 0.06$ at d 27). Debaryomyces hansenii is recognized as a halotolerant yeast with a halotolerance ranging from 0 to $3 \mathrm{M}$, and an optimal salinity of 0.5 to $1 \mathrm{M}$, corresponding to 2.9 and $5.9 \% \mathrm{NaCl}$ in cheese (Gunde-Cimerman et al., 2009). Concomitantly, we observed greater development of $H$. alvei in cheese with a reduced $\mathrm{NaCl}$ content. This gram-negative bacterium, which is frequently detected in smear-ripened cheese (Larpin-Laborde et al., 2011) and hard cheese (Maifreni et al., 2013), is also used as a commercial adjunct to improve cheese flavor (Skovmose, 2003). In fact, H. alvei can produce high levels of aroma compounds including volatile sulfur compounds (e.g., methanethiol, DMDS, dimethyl trisulfide) and branched-chain alcohols (Morales et al., 2004; Irlinger et al., 2012; Pogačić et al., 2015). Accordingly, the levels of some of these compounds at the end of the ripening period was significantly higher in the reduced$\mathrm{NaCl}$ cheese containing higher levels of $H$. alvei. Some of these compounds, such as sulfur compounds, have 
very low perception thresholds and give their uniqueness to a variety of ripened cheeses. However, it is possible that these compounds have a strong effect on the global aroma perception of cheese. Thus, sensory analysis is still needed to evaluate the effect of reducing salt content on such type of cheese.

It is important to point out that the microbial consortia could produce beneficial compounds from amino acids such as aroma compounds, together with undesirable compounds such as biogenic amines. Putrescine and cadaverine were detected at higher levels in cheeses with a reduced $\mathrm{NaCl}$ content than in control cheeses. No appreciable amount of histamine or tyramine was produced in the cheese models, these being considered the most toxic BA (Shalaby, 1996). Putrescine and cadaverine have toxicological effects that are generally considered lower than those of histamine and tyramine, but they may potentiate histamine and tyramine toxicities (Shalaby, 1996). Little is known about the ability of cheese-ripening microorganisms to produce BA. The ability to produce putrescine and cadaverine is present in various $H$. alvei strains isolated from cheeses (Marino et al., 2000; Coton et al., 2012; Maifreni et al., 2013). Moreover, gene sequences for lysine and ornithine decarboxylase, responsible for the production of these 2 BA, were identified in the genome of $H$. alvei strain FB1 (Tan et al., 2014). Some strains of D. hansenii isolated from cheese are also able to decarboxylate ornithine and histidine (Gardini et al., 2006). We suspect that the production of putrescine and cadaverine in our study could be due to the greater development of $H$. alvei. The biosynthesis of $\mathrm{BA}$ in foods requires the availability of free AA. The NPN:TN index was higher in cheeses with a reduced $\mathrm{NaCl}$ content than in the control cheese from d 6 to 27. Thus, the greater development of $H$. alvei combined with higher free AA availability could result in higher BA production in our model cheeses with reduced $\mathrm{NaCl}$ content.

Finally, salt is considered a critical hurdle to control the growth of pathogenic and spoilage microorganisms. Pseudomonas species are considered major cheese spoilage microorganisms that might negatively affect the sensory characteristics of cheese. For example, some strains belonging to this genus can produce pigments (Martin et al., 2011), BA (Martuscelli et al., 2005; Coton et al., 2012), and a wide variety of volatile compounds (Morales et al., 2005b) during ripening, leading to undesirable changes in appearance, texture, flavor, and odor that reduce cheese quality and make products unsaleable. Moreover, this may lead to considerable waste and losses for the food industry (Martin et al., 2011). We detected greater development of P. fragi in cheeses with a reduced $\mathrm{NaCl}$ content than in control cheeses. This is in agreement with results obtained by Tabla et al. (2015), who demonstrated that $\mathrm{NaCl}$ concentration significantly influenced growth of Pseudomonas in a soft ewe cheese.

The presence of $P$. fragi did not affect the overall production of BA and volatile aroma compounds in our cheeses (Supplemental Tables S1 and S2; http://dx.doi. org/10.3168/jds.2015-10502). This is likely because of the low development of this species $(6.19 \pm 0.47 \mathrm{log}$ $\mathrm{cfu} / \mathrm{g}$ at d 27) compared with other microbial species such as H. alvei. Moreover, the production of BA (tyramine, putrescine, and cadaverine) by some strains of Pseudomonas isolated from Pecorino Abruzzese was shown to be strain-dependent (Martuscelli et al., 2005). The production of volatile compounds such as alcohols, esters, and sulfur compounds by $P$. fragi during ripening, with counts close to $10 \mathrm{log} \mathrm{cfu} / \mathrm{g}$ in the outer part of semi-hard cheeses, is also strain-dependent (Morales et al., 2005a).

\section{CONCLUSIONS}

Reducing $\mathrm{NaCl}$ content, as recommended by many health organizations worldwide, by $30 \%$ in an experimental surface-ripened cheese resulted in significant modifications of its microbiological and biochemical properties. Because these properties contribute to cheese quality and consumer acceptability, we recommend further investigations to evaluate the sensory and textural characteristics of representative soft cheeses produced in real conditions with a reduced $\mathrm{NaCl}$ content. Partial substitution of sodium chloride by other chloride salts such as potassium chloride represents an alternative option to limit the negative effects of reducing $\mathrm{NaCl}$ content in soft cheese and should thus be further investigated.

\section{ACKNOWLEDGMENTS}

We thank B. Pollet and G. Lauer (UMR GMPA, Thiverval-Grignon, France), and our undergraduate student, Isabelle Brunetto (IUT Genie Biologique, Lyon, France), for their invaluable technical assistance. This study was funded by RedSel project (FranceAgriMer, Montreuil-sous-Bois, France).

\section{REFERENCES}

ANSES. 2012. Avis de l'agence nationale de sécurité sanitaire de l'alimentation, de l'environnement et du travail relatif au suivi des teneurs en sel des principaux vecteurs entre 2003 et 2011 et simulation des impacts sur les apports en sel de la population française. Accessed Jan. 21, 2016. http://www.anses.fr/fr/system/ files/NUT2012sa0052.pdf.

Arboatti, A. S., M. L. Olivares, N. G. Sabbag, S. C. Costa, S. E. Zorrilla, and G. A. Sihufe. 2014. The influence of sodium chloride reduction on physicochemical, biochemical, rheological and 
sensory characteristics of Mozzarella cheese. Dairy Sci. Technol. 94:373-386. http://dx.doi.org/10.1007/s13594-014-0169-2.

Ayyash, M. M., and N. P. Shah. 2011a. Effect of partial substitution of $\mathrm{NaCl}$ with $\mathrm{KCl}$ on proteolysis of Halloumi cheese. J. Food Sci. 76:C31-C37. http://dx.doi.org/10.1111/j.1750-3841.2010.01901.x.

Ayyash, M. M., and N. P. Shah. 2011b. The effect of substituting $\mathrm{NaCl}$ with $\mathrm{KCl}$ on Nabulsi cheese: Chemical composition, total viable count, and texture profile. J. Dairy Sci. 94:2741-2751. http:// dx.doi.org/10.3168/jds.2010-3976.

Ayyash, M. M., and N. P. Shah. 2011c. The effect of substitution of $\mathrm{NaCl}$ with $\mathrm{KCl}$ on chemical composition and functional properties of low-moisture Mozzarella cheese. J. Dairy Sci. 94:3761-3768. http://dx.doi.org/10.3168/jds.2010-4103.

Ayyash, M. M., F. Sherkat, P. Francis, R. P. W. Williams, and N P. Shah. 2011. The effect of sodium chloride substitution with potassium chloride on texture profile and microstructure of Halloumi cheese. J. Dairy Sci. 94:37-42. http://dx.doi.org/10.3168/ jds.2010-3407.

Bergmark, L., P. H. B. Poulsen, W. A. Al-Soud, A. Norman, L. H. Hansen, and S. J. Sørensen. 2012. Assessment of the specificity of Burkholderia and Pseudomonas qPCR assays for detection of these genera in soil using 454 pyrosequencing. FEMS Microbiol. Lett. 333:77-84. http://dx.doi.org/10.1111/j.1574-6968.2012.02601.x.

Bonaïti, C., F. Irlinger, H. E. Spinnler, and E. Engel. 2005. An iterative sensory procedure to select odor-active associations in complex consortia of microorganisms: Application to the construction of a cheese model. J. Dairy Sci. 88:1671-1684. http://dx.doi. org/10.3168/jds.S0022-0302(05)72839-3.

Coton, M., C. Delbés-Paus, F. Irlinger, N. Desmasures, A. Le Fleche, V. Stahl, M.-C. Montel, and E. Coton. 2012. Diversity and assessment of potential risk factors of gram-negative isolates associated with French cheeses. Food Microbiol. 29:88-98. http://dx.doi. org/10.1016/j.fm.2011.08.020.

Cruz, A. G., J. A. F. Faria, M. A. R. Pollonio, H. M. A. Bolini, R. M. S. Celeghini, D. Granato, and N. P. Shah. 2011. Cheeses with reduced sodium content: Effects on functionality, public health benefits and sensory properties. Trends Food Sci. Technol. 22:276291. http://dx.doi.org/10.1016/j.tifs.2011.02.003.

Doyle, M. E., and K. A. Glass. 2010. Sodium reduction and its effect on food safety, food quality, and human health. Compr. Rev. Food Sci. Food Safety 9:44-56. http://dx.doi.org/10.1111/j.15414337.2009.00096.x.

Dugat-Bony, E., C. Straub, A. Teissandier, D. Onésime, V. Loux, C. Monnet, F. Irlinger, S. Landaud, M.-N. Leclercq-Perlat, P. Bento, S. Fraud, J.-F. Gibrat, J. Aubert, F. Fer, E. Guédon, N. Pons, S. Kennedy, J.-M. Beckerich, D. Swennen, and P. Bonnarme. 2015. Overview of a surface-ripened cheese community functioning by meta-omics analyses. PLoS ONE 10:e0124360 http://dx.doi. org/10.1371/journal.pone.0124360.

EFSA. 2006. Tolerable upper intake levels for vitamins and minerals. Accessed Jan. 21, 2016. http://www.efsa.europa.eu/sites/default/ files/efsa_rep/blobserver_assets/ndatolerableuil.pdf.

Elliott, P., and I. Brown. 2007. Sodium Intakes Around the World. World Health Organization, Geneva, Switzerland.

Gardini, F., R. Tofalo, N. Belletti, L. Iucci, G. Suzzi, S. Torriani, M. E. Guerzoni, and R. Lanciotti. 2006. Characterization of yeasts involved in the ripening of Pecorino Crotonese cheese. Food Microbiol. 23:641-648. http://dx.doi.org/10.1016/j.fm.2005.12.005.

Grummer, J., M. Karalus, K. Zhang, Z. Vickers, and T. C. Schoenfuss. 2012. Manufacture of reduced-sodium Cheddar-style cheese with mineral salt replacers. J. Dairy Sci. 95:2830-2839. http://dx.doi. org/10.3168/jds.2011-4851.

Guinee, T. P., and P. F. Fox. 2004. Salt in Cheese: Physical, Chemical and Biological Aspects. Pages 207-259 in Cheese: Chemistry, Physics and Microbiology. P. L. H. McSweeney, T. M. Cogan, T. P. Guinee, and P. F. Fox, ed. Academic Press, San Diego, CA.

Gunde-Cimerman, N., J. Ramos, and A. Plemenitaš. 2009. Halotolerant and halophilic fungi. Mycol. Res. 113:1231-1241. http:// dx.doi.org/10.1016/j.mycres.2009.09.002.

Helinck, S., M.-C. Perello, P. Deetae, G. de Revel, and H.-E. Spinnler. 2013. Debaryomyces hansenii, Proteus vulgaris, Psychrobacter sp. and Microbacterium foliorum are able to produce biogenic amines. Dairy Sci. Technol. 93:191-200. http://dx.doi.org/10.1007/s13594012-0102-5.

Hystead, E., F. Diez-Gonzalez, and T. C. Schoenfuss. 2013. The effect of sodium reduction with and without potassium chloride on the survival of Listeria monocytogenes in Cheddar cheese. J. Dairy Sci. 96:6172-6185. http://dx.doi.org/10.3168/jds.2013-6675.

Irlinger, F., S. Layec, S. Hélinck, and E. Dugat-Bony. 2015. Cheese rind microbial communities: Diversity, composition, and origin. FEMS Microbiol. Lett. 362:1-11. http://dx.doi.org/10.1093/ femsle/fnu015.

Irlinger, F., and J. Mounier. 2009. Microbial interactions in cheese: Implications for cheese quality and safety. Curr. Opin. Biotechnol. 20:142-148. http://dx.doi.org/10.1016/j.copbio.2009.02.016.

Irlinger, F., S. A. Y. I. Yung, A.-S. Sarthou, C. Delbes-Paus, M.-C. Montel, E. Coton, M. Coton, and S. Helinck. 2012. Ecological and aromatic impact of two Gram-negative bacteria (Psychrobacter celer and Hafnia alvei) inoculated as part of the whole microbial community of an experimental smear soft cheese. Int. J. Food Microbiol. 153:332-338. http://dx.doi.org/10.1016/j. ijfoodmicro.2011.11.022

ISO. 2011. ISO 27871. Cheese and processed cheese-Determination of nitrogenous fractions. International Organization for Standardization, Geneva, Switzerland.

ISO. 2014. ISO 8698-1. Milk and milk products-Determination of nitrogen content-Part 1: Kjeldahl principle and crude protein calculation. International Organization for Standardization, Geneva, Switzerland.

Kamleh, R., A. Olabi, I. Toufeili, N. E. O. Najm, T. Younis, and R. Ajib. 2012. The effect of substitution of sodium chloride with potassium chloride on the physicochemical, microbiological, and sensory properties of Halloumi cheese. J. Dairy Sci. 95:1140-1151. http://dx.doi.org/10.3168/jds.2011-4878.

Larpin-Laborde, S., M. Imran, C. Bonaïti, N. Bora, R. Gelsomino, S. Goerges, F. Irlinger, M. Goodfellow, A. C. Ward, M. Vancanneyt, J. Swings, S. Scherer, M. Guéguen, and N. Desmasures. 2011. Surface microbial consortia from Livarot, a French smear-ripened cheese. Can. J. Microbiol. 57:651-660. http://dx.doi.org/10.1139/ w11-050.

Leclercq-Perlat, M.-N., A. Oumer, J.-L. Bergere, H.-E. Spinnler, and G. Corrieu. 2000a. Behavior of Brevibacterium linens and Debaryomyces hansenii as ripening flora in controlled production of smear soft cheese from reconstituted milk: Growth and substrate consumption. J. Dairy Sci. 83:1665-1673. http://dx.doi.org/10.3168/ jds.S0022-0302(00)75035-1.

Leclercq-Perlat, M. N., A. Oumer, F. Buono, J. L. Bergere, H. E. Spinnler, and G. Corrieu. 2000b. Behavior of Brevibacterium linens and Debaryomyces hansenii as ripening flora in controlled production of soft smear cheese from reconstituted milk: Protein degradation. J. Dairy Sci. 83:1674-1683. http://dx.doi.org/10.3168/jds. S0022-0302(00)75036-3.

Maifreni, M., F. Frigo, I. Bartolomeoli, N. Innocente, M. Biasutti, and M. Marino. 2013. Identification of the Enterobacteriaceae in Montasio cheese and assessment of their amino acid decarboxylase activity. J. Dairy Res. 80:122-127. http://dx.doi.org/10.1017/ S002202991200074X.

Marino, M., M. Maifreni, S. Moret, and G. Rondinini. 2000. The capacity of Enterobacteriaceae species to produce biogenic amines in cheese. Lett. Appl. Microbiol. 31:169-173. http://dx.doi. org/10.1046/j.1365-2672.2000.00783.x.

Martin, N. H., S. C. Murphy, R. D. Ralyea, M. Wiedmann, and K. J. Boor. 2011. When cheese gets the blues: Pseudomonas fluorescens as the causative agent of cheese spoilage. J. Dairy Sci. 94:31763183. http://dx.doi.org/10.3168/jds.2011-4312.

Martuscelli, M., F. Gardini, S. Torriani, D. Mastrocola, A. Serio, C. Chaves-López, M. Schirone, and G. Suzzi. 2005. Production of biogenic amines during the ripening of Pecorino Abruzzese cheese. Int. Dairy J. 15:571-578. http://dx.doi.org/10.1016/j. idairyj.2004.11.008.

Melilli, C., D. M. Barbano, M. Caccamo, M. A. Calvo, G. Schembari, and G. Licitra. 2004. Influence of brine concentration, brine tem- 
perature, and presalting on early gas defects in raw milk pasta filata cheese. J. Dairy Sci. 87:3648-3657. http://dx.doi.org/10.3168/ jds.S0022-0302(04)73503-1.

Mohan, S., and N. R. C. Campbell. 2009. Salt and high blood pressure. Clin. Sci. 117:1-11. http://dx.doi.org/10.1042/CS20080207.

Møller, S. M., T. B. Hansen, U. Andersen, S. K. Lillevang, A. Rasmussen, and H. C. Bertram. 2012. Water properties in cream cheeses with variations in $\mathrm{pH}$, fat, and salt content and correlation to microbial survival. J. Agric. Food Chem. 60:1635-1644. http:// dx.doi.org/10.1021/jf204371v.

Monnet, C., K. Correia, A.-S. Sarthou, and F. Irlinger. 2006. Quantitative detection of Corynebacterium casei in cheese by real-time PCR. Appl. Environ. Microbiol. 72:6972-6979. http://dx.doi. org/10.1128/AEM.01303-06.

Morales, P., I. Feliu, E. Fernandez-Garcia, and M. Nunez. 2004. Volatile compounds produced in cheese by Enterobacteriaceae strains of dairy origin. J. Food Prot. 67:567-573.

Morales, P., E. Fernandez-Garcia, and M. Nunez. 2005a. Production of volatile compounds in cheese by Pseudomonas fragi strains of dairy origin. J. Food Prot. 68:1399-1407.

Morales, P., E. Fernández-García, and M. Nuñez. 2005b. Volatile compounds produced in cheese by Pseudomonas strains of dairy origin belonging to six different species. J. Agric. Food Chem. 53:68356843. http://dx.doi.org/10.1021/jf050717b.

Mounier, J., C. Monnet, T. Vallaeys, R. Arditi, A.-S. Sarthou, A. Helias, and F. Irlinger. 2008. Microbial interactions within a cheese microbial community. Appl. Environ. Microbiol. 74:172-181. http://dx.doi.org/10.1128/AEM.01338-07.

Mounier, J., M. C. Rea, P. M. O'Connor, G. F. Fitzgerald, and T. M. Cogan. 2007. Growth characteristics of Brevibacterium, Corynebacterium, Microbacterium, and Staphylococcus spp. isolated from surface-ripened cheese. Appl. Environ. Microbiol. 73:7732-7739. http://dx.doi.org/10.1128/AEM.01260-07.

Osaili, T. M., A. A. Al-Nabulsi, A. N. Olaimat, R. R. Shaker, M. Taha, and R. A. Holley. 2014. Survival of Escherichia coli O157:H7 during manufacture and storage of white brined cheese. J. Food Sci. 79:M1750-M1755. http://dx.doi.org/10.1111/1750-3841.12547.

Pogačić, T., M.-B. Maillard, A. Leclerc, C. Hervé, V. Chuat, A. L. Yee, F. Valence, and A. Thierry. 2015. A methodological approach to screen diverse cheese-related bacteria for their ability to produce aroma compounds. Food Microbiol. 46:145-153. http://dx.doi. org/10.1016/j.fm.2014.07.018.

Porcellato, D., C. Brighton, D. J. McMahon, C. J. Oberg, M. Lefevre, J. R. Broadbent, and J. L. Steele. 2014. Application of ARISA to assess the influence of salt content and cation type on microbiological diversity of Cheddar cheese. Lett. Appl. Microbiol. 59:207216. http://dx.doi.org/10.1111/lam.12263.

Rulikowska, A., K. N. Kilcawley, I. A. Doolan, M. Alonso-Gomez, A. B. Nongonierma, J. A. Hannon, and M. G. Wilkinson. 2013. The impact of reduced sodium chloride content on Cheddar cheese quality. Int. Dairy J. 28:45-55. http://dx.doi.org/10.1016/j. idairyj.2012.08.007.

Shalaby, A. R. 1996. Significance of biogenic amines to food safety and human health. Food Res. Int. 29:675-690.

Shrestha, S. J. A. Grieder, D. J. McMahon, and B. A. Nummer. 2011a. Survival of Listeria monocytogenes introduced as a postaging contaminant during storage of low-salt Cheddar cheese at 4,10 , and $21^{\circ} \mathrm{C}$. J. Dairy Sci. 94:4329-4335. http://dx.doi. org $/ 10.3168 /$ jds.2011-4219.

Shrestha, S., J. A. Grieder, D. J. McMahon, and B. A. Nummer. 2011b. Survival of Salmonella serovars introduced as a post-aging contaminant during storage of low-salt Cheddar cheese at 4,10 and $21^{\circ}$ C. J. Food Sci. 76:M616-M621. http://dx.doi.org/10.1111/ j.1750-3841.2011.02430.x.

Skovmose. 2003. Cheese flavour options. danlac.

Soares, C., A. L. Fernando, B. Mendes, and A. P. L. Martins. 2015. The effect of lowering salt on the physicochemical, microbiological and sensory properties of São João cheese of Pico Island. Int J. Dairy Technol. 86:409-419. http://dx.doi.org/10.1111/14710307.12198.

Tabla, R., A. Gómez, J. E. Rebollo, and I. Roa. 2015. Salt influence on surface microorganisms and ripening of soft ewe cheese. J. Dairy Res. 82:215-221. http://dx.doi.org/10.1017/S0022029915000023.

Tan, J.-Y., W.-F. Yin, and K.-G. Chan. 2014. Gene clusters of Hafnia alvei strain FB1 important in survival and pathogenesis: A draft genome perspective. Gut Pathog. 6:29 http://dx.doi. org/10.1186/1757-4749-6-29.

Thibaudeau, E., D. Roy, and D. St-Gelais. 2015. Production of brinesalted Mozzarella cheese with different ratios of $\mathrm{NaCl} / \mathrm{KCl}$. Int Dairy J. 40:54-61. http://dx.doi.org/10.1016/j.idairyj.2014.07.013.

WHO/FAO. 2003. Diet, nutrition, and the prevention of chronic diseases: Report of a WHO-FAO Expert Consultation. Joint WHOFAO Expert Consultation on Diet, Nutrition, and the Prevention of Chronic Diseases. World Health Organization, Geneva, Switzerland; Food and Agriculture Organization of the United Nations, Rome, Italy. 